\title{
MODERN WOUND IRRIGATION DEVICE (MWID) REDUCE THE NUMBER OF BACTERIA IN DIABETIC ULCER PATIENTS
}

\section{(Modern Wound Irrigation Device (MWID) Menurunkan Jumlah Bakteri Pada Pasien Dengan Ulkus Diabetikum)}

\author{
Suyanto ${ }^{1}$, Ahmad Ikhlasul Amal ${ }^{2}$ \\ ${ }^{1}$ Medical Surgical Nursing Department, College of Nursing UNISSULA, Semarang \\ ${ }^{2}$ Medical Surgical Nursing Department, College of Nursing UNISSULA, Semarang \\ E-mail: suyanto@unissula.ac.id
}

\begin{abstract}
ABSTRAK
Pendahuluan: Tehnik irigasi bertujuan untuk mengurangi jumlah bakteri pada ulkus diabetikum sehingga diharapkan proses inflamasi menjadi lebih cepat tercapai. Penelitian mengenai alat irigasi pada ulkus diabetikum sangat minimal sehingga penelitian ini bertujuan untuk mengetahui pengaruh modern wound irrigation device (MWID) terhadap penurunan jumlah bakteri pada pendetita ulkus diabetikum. Metode: Metode yang digunakan dalam penelitian ini adalah post test only with control group design. Sebanyak 20 responden dibagi menjadi 10 responden dikelompok intervensi, dilakukan perawatan luka menggunakan alat MWID dan 10 responden dikelompok kontrol dilakukan perawatan luka dengan irigasi manual. Instrumen yang digunakan untuk mengetahui jumlah bakteri menggunakan hasil laboratorium dari pus ulkus diabetikum. Hasil: rerata jumlah bakteri pada kelompok kontrol sebanyak 59x109 $\mathrm{cfu} / \mathrm{ml}$, sedangkan rerata jumlah bakteri pada kelompok intervensi yakni $30,4 \times 10^{9} \mathrm{cfu} / \mathrm{ml}$. Hasil uji analisis independen t test didapatkan perbedaan yang signifikan antara rata-rata jumlah bakteri pada kelompok kontrol dan kelompok intervensi dengan $p$ value $(0,001<0,005)$. Diskusi: penggunaan alat MWID saat irigasi luka terbukti mampu mengurangi jumlah bakteri pada ulkus diabetikum dibandingkan dengan penggunaan teknik irigasi manual. Pengembangan riset alat MWID adalah dengan memodifikasi output irigasi untuk mengurangi bakteri anaerob pada luka gangren.
\end{abstract}

Kata kunci: Ulkus diabetikum, Irigasi luka, Jumlah bakteri

\begin{abstract}
Introduction: One of the microvascular complications in patients with diabetes mellitus is a diabetic ulcer. One of he goals of care in diabetic ulcers is to reduce infection in the wound area by doing a cleansing method particularly utilizing irrigation techniques. Irrigation technique aims to reduce the number of bacteria in the wound so that the inflammatory process is expected to be more quickly achieved. Many diabetic ulcer care-related research but research on irrigation tools on diabetic ulcers are very minimal. This study aims to determine the effect of Modern Wound Irrigation Device (MWID) to decrease the amount of bacteria in patients with diabetic ulcers. Method: This study was utilized quasi-experimental post test only with control group design. A total of 20 respondents in this study were divided into 10 respondents for intervention group that was given wound care using MWID. 10 respondents as a control group that was given manual irrigation wound care. Results: The average number of bacteria in the intervention group is $30,4 \times 10^{9}$ colonies $/$ ml, while the average number of bacteria for the control group is $59 \times 10^{9}$ colonies $/ \mathrm{ml}$. Analysis with independent $t$ test was found that there is no significant difference between the average number of bacteria in the intervention and control groups with a $p$ value of $(0.001<0.005)$. Discussion: the use of MWID for current wound irrigation is proven can reduce the number of bacteria on diabetic ulcers as compared with manual irrigation technique. Further developmental research utilizes MWID tool is to modify the output of irrigation to reduce anaerobic bacteria for gangrene wound.
\end{abstract}

Key words: Diabetic Ulcer, Wound irrigation, amount of bacteria

\section{INTRODUCTION}

Patients with diabetes mellitus in Indonesia amounted to 7.292 million in 2011 and is predicted to increase to 11.802 million in 2030 (Weil \& Shaw, 2011). Indonesia is in the 4th ranks in terms of a number of the people with diabetes mellitus in the world. Riskesdas (2013) stated that the national prevalence of
DM patients in Indonesia that was founded based on interviews diagnosed by doctors is about $2.1 \%$. The increasing number of diabetes mellitus also causes increased incidence of complications of diabetes, one of whom was wounded in the leg. Diabetic ulcers or diabetic foot ulcer is one of the chronic complications of diabetes. Approximately $29 \%$ of diabetics will experience injury to his leg. 
The most important function of wound care is to prevent infection. The number of bacteria will determine whether the wound is infected or not. Infection by bacteria that colonize surrounding the tissue will cause damage. Wound cleansing is one of the best efforts to decrease the bacterial colonization (Beanchi \& Janice, 2000 in Asmorohadi, 2013). Common actions undertaken to clean the open wound and prevent the pathogen contamination is cleansing technique. The cleansing technique used is irrigation.

Irrigation is a flow through the wound with the liquid based on certain pressure. The pressures exerted for irrigation vary from 0.5 psi to 15 psi. An essential part of wound irrigation sufficient amount of sterile fluid and optimal irrigation pressure. The amount of the fluid that needed for irrigation will depend on the type of wound and the level of contamination (Asmorohadi, 2012).

Irrigation is included in the mechanical debridement, using mechanical pressure to get rid of dead tissue. The high pressure will push water to clean the wound of dead tissue or bacteria. Artrihpi is one of the tools that were created for wound irrigation utilizing the principle of high-pressure irrigation. That tool can be created using a $50 \mathrm{cc}$ syringe, needle and pressure number 20 as a control pressure gauge. Relevant research was shown that there was no significant difference between the use of artriphi by irrigation using a syringe on wound healing DM (Asmorohadi, 2012). Results of a preliminary study on Sultan Agung Islamic Hospital obtained that nurses who perform irrigation during wound care still use $\mathrm{NaCl}$ bottle without knowing how is the irrigation pressure.

Proper wound care techniques to reduce the number of bacteria is cleansing by irrigation. Much research has been done on the effects of irrigation on wound care. But researchers have found in recent research on the use of modern irrigation tool in patients with diabetic foot ulcers, so researchers are interested to see the effect of modern wound irrigation device (MWID) toward a number of bacteria in patients with diabetic ulcers

\section{METHOD}

Researchers have used a quasiexperimental design approach to post-test only with the control group, in which the measurements were taken 1 times after the experiment. Test performed by measuring the number of bacteria using laboratory results from diabetic ulcers exudates.

The intervention group performed using MWID wound care, while the control group performed the treatment of wounds using a manual irrigation. Patients who have diabetic ulcers in Islamic Hospital Sultan Agung Semarang used as the study population. The sampling technique used is consecutive sampling

Inclusion criteria in this study are patients who have diabetic ulcers with the University of Texas grade 1-2 A-D stage, patient age $>30-60$ years old years old and suffering from diabetes $0-15$ years.

\section{RESULT}

The number of samples in this study was 20. Divided into two groups: 10 intervention and 10 control group. Characteristics of the participant such as age, gender, and length of diabetes were also included to gather deeper understanding.

Table 1 shows the mean of the age in the control group was lower than the intervention

Table 1. Characteristics of the participantts in terms of age, length of diabetes mellitus, and amount of bacteria)

\begin{tabular}{lccc}
\hline \multicolumn{1}{c}{ Variable } & Mean \pm SD & $\begin{array}{c}\text { Min- } \\
\text { Maks }\end{array}$ & n \\
\hline Age: & & & \\
$\begin{array}{l}\text { a. Control } \\
\text { b. Intervention }\end{array}$ & $49.0 \pm 6.6$ & $38-59$ & 10 \\
\hline $\begin{array}{l}\text { Length of DM: } \\
\text { a. Control }\end{array}$ & $4.0 \pm 1.5$ & $2-7$ & 10 \\
b. Intervention & $4.8 \pm 2.1$ & $3-8$ & 10 \\
\hline $\begin{array}{l}\text { Amount of } \\
\text { bacteria: }\end{array}$ & $60.8 \pm 24.9$ & $28-100$ & 10 \\
$\begin{array}{l}\text { a. Control } \\
\text { b. Intervention }\end{array}$ & $44.9 \pm 5.15$ & $11-81$ & 10 \\
\hline
\end{tabular}


Modern Wound Irigation Device (MWID) Reduce (Suyanto, Ahmad Ikhlasul Amal)

Tabel 2. Characteristics of the participant in terms of gender

\begin{tabular}{lcccc}
\hline \multirow{2}{*}{ Variable } & \multicolumn{2}{c}{ Control Group } & \multicolumn{2}{c}{ Intervention Group } \\
\cline { 2 - 5 } & Frekuensi & \% & Frekuensi & $\%$ \\
\hline Gender & & & & 30 \\
a. Male & 4 & 40 & 3 & 70 \\
b. Female & 6 & 60 & 7 & $\%$ \\
\hline
\end{tabular}

Table 3. The difference in a number of bacteria between the intervention and control groups after treatment

\begin{tabular}{lccc}
\hline \multicolumn{1}{c}{ Variable } & Mean \pm SD & p value & n \\
\hline Amount of bacteria & & & \\
a. Control group & $59.0 \pm 17.46$ & $0,001^{*}$ & 10 \\
b. Intervention group & $30.4 \pm 13.58$ & & 10 \\
\hline
\end{tabular}

*) with $\alpha 0,05$

group. Average in terms of length of diabetes in control group was lower than the intervention group. The number of bacteria before the treatment in the control group more than the average number of bacteria in the intervention group.

Table 2 illustrates that the most dominant both in the control group and the intervention group were women.

Table 3 shows the results of analysis using parametric tests independent $t$ test found a significant difference between the mean number of bacteria control group with the intervention group $(\mathrm{p}$ value $=0.001)$.

\section{DISCUSSION}

The number of bacteria in the samples show that there is a process of colonization and infection. Edward \& Harding (2004) found that the increase in bacterial colonization of the wound does not depend on the amount and type of bacteria, but also influenced by the immune response of patients as well as the differences and interactions between species of bacteria in the wound.

Amin and Doupis (2016) stated that the number of bacteria in diabetic ulcers is affected by the anti-bacterial agent that is used in the treatment of wounds. In anaerobic bacteria, metronidazole gel can be used to adjust the humidity around the wound area. The wound infection pattern by bacteria are commonly irregular, and therefore the evaluation of the number of microbes and bacterial sensitivity is important for the management of bacteria in diabetic ulcers.

The immune system that every possible respondent may have could give impact on bacterial colonization resulting in wound healing. Xu et al. (2007) stated that there is a lot of possibility and much of an explanation about how bacteria can impair wound healing.

The results of paired t test showed a significant difference average amount of bacteria in the intervention group before and after irrigation with MWID ( $\mathrm{p}$ value $=0.05$ ). These results prove that the method of wound cleansing that uses the pressure principle of 10-15 psi is effective in the treatment of diabetic ulcer patients. Rodeheaver and Ratliff (2008) which also states that wound irrigation tool which is the irrigation pressure can be measured is the best method to do by the wound care practitioners.

Cleaning the wound by irrigation method is the most important stages to improve the wound healing process as long as it uses the proper pressure. The right pressure when irrigation is often, recommended by some articles, especially for chronic wounds (Nicks et al., 2010).

The results also show that there is a decreasing in the number of bacteria after intervention utilizing MWID. This is also supported by studies of (Longmire, Broom, and Burch (1987) in Nicks et al. (2010)), that the wound irrigation which uses pressure 12 
psi can fight bacterial adhesions in diabetic ulcers.

In this study, there are several limitations including the type of bacteria has not been checked, the room contamination may affect the results of measurements of a number of bacteria and forms a spray irrigation MWID output can not direct contact with wounds that have a tunnel.

\section{CONCLUSION}

Irrigation technique for diabetic wound utilizing MWID has proven reducing the number of bacteria compared with manual irrigation. Researchers suggest that development of further research related to utilization of MWID need to modify the output of irrigation to reduce anaerobe bacteria in the diabetic wound.

\section{REFERENCE}

Asmorohadi, A., Gayatri, D., \& Dahlia, D. (2013). Efektifitas alat irigasi arthripi terhadap penyembuhan ulkus diabetikum di rsu tugu semarang dan rsu kota semarang. Thesis, tidak dipublikasikan.

Clayton, W,Jr \& Tom, A.E. (2009). A review of the pathophysiology: classification and treatment of foot ulcer in diabetic patient. Diakses dari http://www. clinical_dabetes_mellitus./article.htm

Dahlan, S.M. (2011). Statistik untuk kedokteran dan kesehatan. Jakarta: Salemba Medika

Dewi, A. (2006). Hubungan aspek-aspek perawatan kaki diabetes dengan kejadian ulkus kaki diabetes pada pasien Diabetes Mellitus. Thesis, Tidak dipublikasikan

Fauci, A.S., Kasper, D.L., Longo,D., Braunwald,E., Hauser, S.L, Jameson,J.L., et.al. (2008). Harrison's: Principles od internal medicine $\left(17^{\text {th }}\right.$ ed). New York Mc Graw Hill

Lavery, L.A., McGuire, J..B., Baranoski, S., \& Ayello, E.A. (2008). Diabetic foot ulcer. Journal of diabetes and its complications, 16: 153-158

Moffat, C., Martin, R., Smithdale, R. (2007).
Leg ulcer management. Publishing, Oxford.

National Diabetes Facts Sheet. (2011). Fast fact on diabetes. Diakses dari http:/www. cdc.gov/diabetes

Nicks, B.A., Vello, E.A., Woo, K., NitzkiGeorge, D., \& Sibbald, R.G. (2010). Acute wound management: revisiting the approach to assessment, irrigation, and closure considerations. International Journal of Emergency Medicine, 3(4): 399-407

Norwood, D.V. (2011). Diabetic foot ulcer. EBSCO Publishing

Riset Kesehatan Dasar (RISKESDAS) 2013, Badan Penelitian dan Pengembangan Kesehatan Kementerian Kesehatan RI, accessed:23/04/2016, <http://www. litbang.depkes.go.id/sites/download/ buku laporan/lapnas riskes das2013/ Laporan riskesdas 2013.pdf>

Rowland, K. (2009). Wound healing perspectives: diabetic foot ulcers. National healing corporation, 6 (4)

Sabri, L., \& Hastono, S.P. (2006). Statistik kesehatan. Edisi revisi. Jakarta: FKM UI.

Sastroasmoro, S \& Ismael, S. (2010). Dasar - dasar metodologi penelitian klinis. (Ed.2). Jakarta : Sagung Seto.

Singh, N., Armstrong,D.G., \& Lipsky, B.A. (2005). Preventing doot ulcers in patients with diabetes. JAMA, 293 (2)

Smeltzer, S.C., Bare, B.G., Hinkle, J.L., \& Cheever, K.H. (2008). Brunner \& Suddarth's textbook of medical surgical nursing (11th ed.). Philadelphia : Lippincott Williams \& Wilkins.

Suriadi. (2004). Perawatan luka, Edisi 1. Jakarta; Sagung Seto.

Suyono, S. (2006). Masalah Diabetes Mellitus di Indonesia. Buku Ajar Ilmu Penyakit Dalam edisi 3. Jakarta: Balai penerbit Fakultas Kedokteran Universitas Indonesia

Vancouver Costal Health. (2010). Diabetic foot care: You dan your feet. Vancouver Coastal Health. Diakses dari http:// www.vch.eduhealth.ca

Weil, C. \& Shaw, J. (2011). IDF diabetes atlas: global estimates of prevalence of diabetes for 2011 and 2030. Diabetes research and clinicl practice, 94, 311321. 